Jan., Feb., Mar., 1952

\title{
Some Common Hawks, Their Habits and Habitat
}

Mrs. John Hubbard, Jr., Grenfell, Sask.

Hawks are like people, some like one part of the country and some another part. Here at Grenfell, where we have both prairie and parkland within a few miles of each other, we see many varieties.

Probably our most common hawk is the Red-tail, the resident buzzard in this locality. The phase here is quite a light one with pronounced red tail and narrow dark band across the abdomen. I have seen young birds in early fall that were almost pure white, and though I am not quite certain, believed them to be Red-tails. Here the Red-tail is a very beneficial bird and in my 10 years of married life on the farm have never known one to rob a chicken yard. I've also seen house sparrows nesting in the lower storeys of their bulky tree nests!

Another buzzard hawk, but not quite as common here as the Red-tail, is the Swainson. Everyone who has travelled on the prairies knows this hawk; he is the big chappy with the dark band across his upper chest who sits on a telephone pole and waits for you to knock down his dinner. Mice, gophers, and rabbits that fall prey to passing cars are his meat. He also follows the farmer round the fields performing amazing feats of aeronautics as he waits for him to turn up mice, shrews and gophers while working combine stubble in fall or spring, and while combining swathed grain or picking up stooks in fall. His clean-cut outlines in flight, his familiar telephone pole observation post, his amazing skill in flying and the way he has adapted himself to fit our modern civilization have made the Swainson among the best loved of the prairie hawks.

A common hawk here where sloughs and bush abound is the spectacular Marsh hawk, the male slateblue and white, and the female rusty-brown and white; both with distinctive white rump. They beat up and down over the brush and sloughs looking for mice, shrews, insects and, I insist, nestling birds. We wage constant war with this species as to the possession of our young chickens. We have found that a pair of these hawks nesting within half a mile of the buildings mean trouble. One year while I was still unsuspicious I lost 60 of 100 young chickens before John shot the offending female. Another year a pair started a raid on the chicken yard but the male was shot, and the female, after a half-day's search for him, pulled out and was not seen again. It is my belief that a bird that is such a constant chicken thief must also take a heavy toll of small birds, especially ground nestlings. A chart I have shows $41 \%$ of their food to be small birds. The Marsh hawk builds its nest on the ground.

A common hawk in the migration season is the American Sparrow hawk, that pretty little falcon who deserves a much better name. Might I suggest Varied hawk, Vari-coloured hawk or even Flaming hawk as a better name for this insect-eating falcon. This hawk nests in old woodpecker holes in trees and should therefore nest in this locality, but we have no knowledge of its nesting near here for years. With the thinning of the bush suitable nesting sites are getting scarcer.

Before we moved to our present farm a tall poplar commanded the lawn in front of my father-in-law's bee yard. Every spring and fall a Sparrow hawk would stay for days in this poplar, making frequent spectacular drops to the lawn. I suspected him of picking up bees but if he did he did not take them in harmful quantities, and as Mr. Hubbard suggested probably picked on the less active drones. 


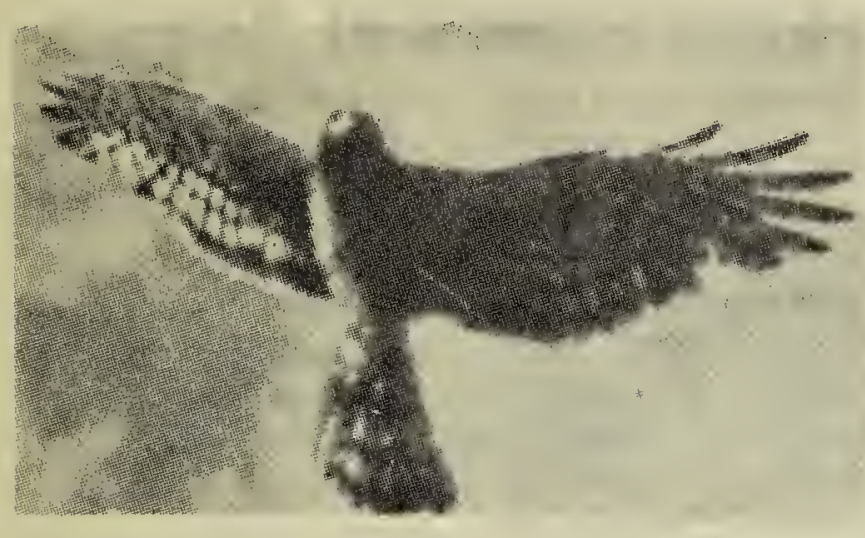

The true chicken hawks, the bluebacked, round-winged, long-tailed accipters such as the Cooper's and Sharp-shinned cause us little worry. We only see them in migration when we have no small chickens on the loose. They are hated by all smail birds and when one does turn up kingbirds, sparrows, blackbirds ali join in chasing them off. A few years ago we saw these birds during the summer and believed a few nested here. Now with a lot more of the land cleared we no longer see them except in migration.

The two Rough-legged hawks, and the larger falcons we see only in migration, and the Goshawk as a rare winter visitor.

Both the Bald and Golden eagle pay us sporadic visits, sometimes of but a few moments duration, at other times hanging around less habited parts of the district for weeks. Young of both the Bald and Golden eagles have come right into our yard at different times. A few years ago a young Golden eagle picked up a pullet but dropped ii when the men who were only a few yards away shouted. However, this boldness seems to go with youth and I've never seen an adult so close.

\section{Across Western Canada with the Birds in December}

\section{(Continued from page 5)}

to be Grosbeaks, doubtless from northern regions colder than they liked.

Where we came to rest in the northern part of the Okanagan Valley, a bright colored pheasant awakened us each dawn with his hoarse crowing and could be seen of a morning walking proudly through the pines and past the house, even in the city, built as it is, on hills and in hollows.

\section{BIRD SONG RECORDS}

\section{Harold Kreinge, Hawarden}

I wonder if our readers know about the Vinylite bird-song records sold by the T. A. Allen Company of Toronto. Volume 1 records 72 calls and songs of American birds, and Volume 2 records 50 calls of songs of birds. Many of the recordings are realistic and wonderfully natural. I have both of these volumes as well as a third which records the calls of 24 Eastern North American frogs and toads. It is splendid.

\section{A BOLT FROM THE BLUE}

\section{By Arthur Ward, Swift Current}

It was approaching dusk, and standing in front of one of the traps in order to let a banded bird free, there came a resounding thud against the back of the trap. Momentarily I was so taken aback that the hawk recovered and flew away. It had seen the bird (Harris Sparrow) in the trap and apparently had struck the trap feet first. Had it been head first it would have knocked itself out. It all happened so quickly that I could not identify it, but it looked like a Cooper's Hawk.

"I enjoy every article, and would not like to miss a single copy. I find Arch Budd's floral offerings most interesting, and love to walk with Elizabeth Cruickshank on her little tours and trips to the Valley."

-Mrs. Arthur Thompson, Rangor.

\section{APPRECIATION}

"I get an opportunity to see quite a few Society magazines but I believe the BLUE JAY is the most alive of any. Folks from the utmost places in the province have a finger in itand what a change from that mimeographed sheet!"

-P. H. Du Boulay, Montreal. 